Maria Sobieszczyk

ORCID: 0000-0002-0185-9795

Katarzyna Wojciechowska

ORCID: 0000-0003-4249-8524

\title{
Wybrane możliwości współpracy środowiska rodzinnego i przedszkolnego
}

\section{Wprowadzenie}

Placówki przedszkolne jako placówki zapewniające warunki pomyślnego rozwoju dzieciom są powołane do wypełniania określonych zadań, stanowiących o jej funkcjach wobec dziecka, rodziny i społeczeństwa. Współpracując z rodziną i środowiskiem, przedszkole sprawuje opiekę nad zdrowiem i bezpieczeństwem dzieci oraz stymuluje ich wszechstronny rozwój. Zadaniem przedszkola jest także realizacja działalności profilaktycznej i kompensacyjnej oraz przygotowanie wychowanków do podjęcia nauki w szkole. Funkcje i zadania przedszkola są zatem skierowane $\mathrm{z}$ jednej strony na dziecko, jego właściwy rozwój i wychowanie, z drugiej, odnoszą się do potrzeb życia społecznego i związanej z tym sytuacji rodziny. Najważniejszymi klientami przedszkola są dzieci i ich rodzice. Wśród podmiotów zaangażowanych w tworzenie przedszkola, które zadowalałoby beneficjentów są nauczyciele przedszkola i cały personel wraz z dyrekcją placówki. Istotną rolę odgrywa przede wszystkim organizacja, a następnie realizacja procesu edukacyjnego. Aby współpraca danej placówki i rodziców układała się poprawnie, konieczne jest m.in. przekonanie obu stron do konieczności takiej współpracy, systematyczna wymiana informacji o dziecku, jego postępach i trudnościach, codzienne wspieranie się w różnych sytuacjach oraz zaangażowanie nauczycieli i rodziców w stworzenie 
przyjaznej, partnerskiej atmosfery w grupie/klasie szkolnej jak i całej społeczności danej placówki ${ }^{1}$.

Pobyt dziecka w przedszkolu ma niewątpliwie bardzo korzystny wpływ na jego rozwój. Dziecko przebywa w naturalnym i profesjonalnie przygotowanym środowisku, co sprzyja poznawaniu i rozumieniu najbliższego otoczenia i świata, nabywaniu umiejętności przez działanie. Programy edukacyjne zgodnie $z$ obowiązującą podstawą programową realizowane w przedszkolach stwarzają możliwości zdobywania różnorodnych doświadczeń, a także uczestniczenia w zróżnicowanych i ciekawych zajęciach nie tylko dzieciom ale ich rodzicom oraz innym członkom rodzin (starszemu lub młodszemu rodzeństwu, dziadkom czy opiekunom). Możliwości szerokiej współpracy przedszkola z rodzicami możliwe są we wszystkich obszarach edukacyjnych realizowanych w przedszkolu. Ramy tego opracowania nie pozwalają odnieść się do wszystkich, dlatego przykłady takiej wzorowej współpracy prezentujemy przede wszystkim w odniesieniu do obszaru edukacji zdrowotnej i przyrodniczej z elementami edukacji ruchowej i kulturowo-estetycznej.

\section{Możliwości współpracy przedszkola z rodzicami w obszarze edukacji zdrowotnej}

Większość zachowań człowieka w codziennym życiu ma bezpośredni lub pośredni związek ze zdrowiem. Zachowania te mogą być reaktywne, nawykowe lub celowe. Niektórzy autorzy odróżniają termin „zachowania zdrowotne” odnoszący się do postępowania podjętego intencjonalnie w celu przywrócenia, utrzymania lub doskonalenia zdrowia od "zachowań związanych ze zdrowiem” - automatycznych, nieintencjonalnych ${ }^{2}$. Zachowania zdrowotne dzieli się także na:

- sprzyjające zdrowiu (prozdrowotne, pozytywne), do których można zaliczyć: aktywność fizyczną, racjonalne żywienie, utrzymywanie czystości ciała i otoczenia, zapewnienie bezpieczeństwa (np. w ruchu drogowym), utrzymanie właściwych relacji między ludźmi, radzenie sobie ze stresem;

1 E. Tąpała, Rodzice w szkole, „Życie Szkoły” 2003, nr 5, s. 316.

2 B. Woynarowska, Zdrowie $i$ szkoła, Wydawnictwo Lekarskie PZWL, Warszawa 2000, s. 68 . 
- ryzykowne dla zdrowia (antyzdrowotne, negatywne) to przede wszystkim: palenie tytoniu, nadużywanie alkoholu, używanie środków psychoaktywnych, wpływających na zachowania autoagresywne.

Niedostatki w zakresie zachowań sprzyjających zdrowiu mogą również powodować ryzyko dla zdrowia. Zachowania zdrowotne kształtują się od wczesnego dzieciństwa w procesie socjalizacji, pod wpływem bardzo różnorodnych czynników, w tym wzorów i instrukcji przekazywanych przez rodziców, rówieśników, szkołę, religię, społeczność lokalną, środki masowego przekazu i reklamy. Dzieciństwo i młodość decydują w istotnym stopniu o zachowaniach zdrowotnych człowieka w wieku dorosłym³ ${ }^{3}$.

Suma zachowań zdrowotnych, zarówno sprzyjających jak i niesprzyjających zdrowiu, postaw i ogólnej filozofii życia składa się na styl życia człowieka. W rozumieniu potocznym stanowią go określone zespoły zachowań, przekonań i nastawień ujawniające się u danego człowieka w doświadczanych przez niego sytuacjach życia codziennego. Nauki psychologiczne określają styl życia jako zespół typowych dla określonego układu cech osobowości zachowań i reakcji pojawiających się w różnych sytuacjach życiowych. Definicje socjologiczne natomiast ujmują styl życia jako zakres i formy codziennych zachowań jednostek lub grup, specyficzne dla ich usytuowania społecznego ${ }^{4}$. Prezentowany przez jednostkę styl życia może wzmacniać jej potencjał zdrowotny bądź prowadzić do jego osłabienia, stąd możemy mówić o prozdrowotnym lub antyzdrowotnym jego charakterze. Styl życia o charakterze prozdrowotnym cechuje obecność zachowań nakierowanych na umacnianie i poprawę zdrowia przy jednoczesnej eliminacji zachowań ryzykownych, zagrażających zdrowiu ${ }^{5}$. Człowiek prowadzący prozdrowotny styl życia dba o sprawne funkcjonowanie swojego organizmu, posiada zdolność radzenia sobie z problemami emocjonalnymi i psychicznymi, a także posiada umiejętność reagowania na wyzwania środowiska i pokonywania sytuacji trudnych. Jest to człowiek zdrowy

$3 \quad$ Ibidem, s. 68.

4 A. Siciński, Styl życia - problemy pojęciowe i teoretyczne, [w:] A. Siciński (red.), Styl $\dot{z}$ ycia. Koncepcje i propozycje, PWN, Warszawa 1976, s. 15.

5 A. Gaweł, Pedagodzy wobec wartości zdrowia, Wydawnictwo Uniwersytetu Jagiellońskiego, Kraków 2003, s. 23. 
w sensie społecznym, czyli posiada predyspozycje psychofizyczne, które pozwalają na spełnianie kierowanych do niego oczekiwań w związku z pełnionymi przez niego funkcjami i rolami społecznymi, a jednocześnie ma możliwość życia w sposób satysfakcjonujący ${ }^{6}$. Zgodnie zatem z definicją zdrowia pomnażać jego potencjał będzie jednostka, na styl życia której składać się będą zachowania prozdrowotne w wymiarze fizycznym, psychicznym i społecznym. Prowadzenie przez jednostkę prozdrowotnego stylu życia jest możliwe dzięki uczestniczeniu już najmłodszych dzieci w procesie edukacji zdrowotnej.

Maciej Demel podkreśla, iż wychowanie zdrowotne jest nierozerwalną częścią procesu kształtowania wielostronnej osobowości człowieka. Zgodnie z tą koncepcją cele edukacji zdrowotnej obejmują:

- wytwarzanie nawyków bezpośrednio lub pośrednio związanych z ochroną i doskonaleniem zdrowia fizycznego i psychicznego;

- wyrabianie odpowiednich sprawności;

- nastawienie woli i kształtowanie postaw umożliwiających stosowanie zasad higieny, skuteczną pielęgnację, zapobieganie chorobom i leczenie;

- pobudzanie pozytywnego zainteresowania sprawami zdrowia przez epizodyczne i systematyczne wzbogacanie i pogłębianie wiedzy o sobie, jak też o prawach rządzących zdrowiem publicznym.

Autor uważa, że wskaźnikiem skuteczności są korzystne zmiany zachowań zdrowotnych?

Edukacja zdrowotna w przedszkolu wiąże się ze zdobywaniem określonego zasobu informacji o zdrowiu, a także ze współuczestniczeniem w definiowaniu własnych problemów zdrowotnych i określaniu czynników wpływających pozytywnie i negatywnie na zdrowie. W edukacji przedszkolnej akcent winien być również położony na dostarczanie dzieciom argumentów, które świadczą o korzyściach płynących z dbania o własne zdrowie i pomnażania jego potencjału. Dzięki temu zaczną dostrzegać sygnały zagrażające zdrowiu oraz będą zdawać sobie sprawę z tego, że zdrowie jest najwyższą wartością, dzięki której można osiągnąć wytyczone cele i wpływać na jakość swego życia.

$6 \quad$ M.M. Śliwa, Wychowanie zdrowotne. Zarys teorii i metodyki, Polskie Towarzystwo Oświaty Zdrowotnej, Katowice 2001, s. 62.

7 M. Demel, Pedagogika zdrowia, WSiP, Warszawa 1980, s. 69. 
Jeżeli dziecko będzie lokowało zdrowie na wysokich pozycjach w hierarchii wartości, to samo, lub przy pomocy dorosłych, podejmie działania prozdrowotne w najróżniejszych sytuacjach życia codziennego ${ }^{8}$.

Warunkiem powodzenia edukacji zdrowotnej w przedszkolu jest stawianie właściwych celów i konsekwentna ich realizacja. Wynikać one powinny z właściwości psychofizycznych dzieci, paradygmatu edukacji podmiotowej, traktowania zdrowia jako wartości autotelicznej, programu wychowania w przedszkolu lub podstawy programowej. Cele edukacji zdrowotnej w przedszkolu obejmują:

- rozbudzanie zainteresowań dziecka własnym zdrowiem i rozwojem;

- rozwijanie umiejętności rozróżniania czynników pozytywnie i negatywnie wpływających na własne zdrowie i rozwój;

- rozwijanie podstawowych umiejętności dbania o zdrowie swoje i innych;

- rozwijanie zachowań sprzyjających zdrowiu i bezpieczeństwu;

- poznawanie zagrożeń cywilizacyjnych dla własnego zdrowia;

- rozwijanie umiejętnego zachowania się w przypadku kontaktu z przedmiotami niebezpiecznymi, toksycznymi, wybuchowymi, łatwopalnymi;

- wyrabianie nawyków zdrowotno-kulturalnych;

- wyrabianie właściwego stosunku do osób starszych, kalekich i chorych, kształtowanie odpowiedzialności za wzmacnianie i pomnażanie własnego zdrowia i innych;

- kompensowanie ujemnych zagrożeń cywilizacyjnych;

- właściwe reagowanie na cierpienie rówieśników i dorosłych;

- dostosowanie funkcji własnego ciała do norm społeczno-kulturalnych;

- dostrzeganie zależności pomiędzy stanem naturalnego środowiska a zdrowiem i samopoczuciem własnym i innych osób.

Biorąc pod uwagę dotychczasowe rozważania można przyjąć, że przedszkolna edukacja zdrowotna ma trzy aspekty. Pierwszy z nich dotyczy przekazywania dzieciom wiedzy o zdrowiu, sposobach jego ochrony i umacniania. Drugi aspekt wiąże się z kształtowaniem zachowań dzieci służących zdrowiu. Trzeci aspekt obejmuje te działania,

$8 \quad$ K. Żuchelkowska, K. Wojciechowska, Promocja zdrowia w edukacji dzieci przedszkolnych, MARGRAFSEN, Bydgoszcz 2000, s. 18. 
które prowadzą do wytworzenia pozytywnych postaw wobec zdrowia i traktowania go jako najwyższej wartości ${ }^{9}$. Istnieje także, naszym zdaniem, czwarty aspekt tego procesu i dotyczy on włączenia w edukację zdrowotną i promowanie zdrowia rodziców dzieci.

W przedszkolu edukatorem zdrowia jest nauczyciel. Jest on osobą odpowiedzialną za przebieg edukacji dziecka przedszkolnego. Celem jego pedagogicznej działalności jest prawidłowe ukształtowanie osobowości dziecka. W związku z tym, zadaniem nauczyciela jest organizowanie środowiska przedszkolnego, dbanie o wszechstronny rozwój dzieci, właściwe kształtowanie ich postaw, przekonań i zainteresowań, wyrabianie umiejętności i sprawności oraz stopniowo poszerzanie ich wiedzy. Całej pracy wychowawczej nauczyciela powinna przyświecać przede wszystkim troska o zdrowie i bezpieczeństwo swoich podopiecznych. Wynika stąd konieczność włączania się do działań profilaktycznych, stymulujących, kompensacyjnych i korektywnych ${ }^{10}$.

Dlatego, jeśli nauczyciel chce być kompetentny i wiarygodny, musi umieć oceniać i znać sztukę osiągania tego, co dla małych dzieci jest realne i możliwe. Dlatego oceniając osiągnięcia prozdrowotne dzieci w wieku przedszkolnym, winien uwzględniać:

- dbanie o zdrowie własne i innych oraz współpracę z dorosłymi w tym zakresie;

- rozróżnianie czynników wpływających pozytywnie i negatywnie na zdrowie i rozwój;

- rozpoznawanie i odpowiednie reagowanie na zagrożenia dla zdrowia i życia;

- postawę i stosunek do aktywności ruchowej;

- poziom i postępy w rozwoju sprawności motorycznej i ogólnej sprawności fizycznej ${ }^{11}$.

Nauczyciel pełniąc rolę wychowawcy zdrowia, powinien spełniać pewne warunki, aby jego wychowankowie zrozumieli istotę troski o zdrowie, należycie je cenili i racjonalnie postępowali. Jednym z nich jest konieczność posiadania szerokiej wiedzy merytorycznej

$9 \quad$ J.B. Karski, Praktyka i teoria promocji zdrowia, wybrane zagadnienia, Wydawnictwo CeDeWu, Warszawa 2003, s. 21.

10 A. Klim-Klimaszewska, Pedagogika przedszkolna, Polski Instytut Wydawniczy, Warszawa 2005, s. 115.

11 Ibidem, s. 26. 
z zakresu ochrony zdrowia, sposobów jego doskonalenia oraz ratowania. Wachlarz wiadomości, które posiada nauczyciel animator zdrowia dziecka jest szeroki i obejmuje m.in. zasady racjonalnego odżywiania, sposoby walki ze stresem, uzależnieniami, zdrowotne aspekty aktywności ruchowej, zapobieganie chorobom cywilizacyjnym i udzielanie pierwszej pomocy. Ważne są również umiejętności metodyczne, które umożliwiają nauczycielowi prawidłową organizację i prowadzenie edukacji zdrowotnej. Wiąże się z tym umiejętność postawienia prawidłowej diagnozy i dokonywanie analizy, a także wykorzystywanie aktywnych narzędzi badawczych, które pozwalają mu dostosować treści programowe do potrzeb poszczególnych dzieci z danego środowiska, z uwzględnieniem ich wieku, specyfiki rozwoju i zainteresowań. Aby dzieci lokowały zdrowie na wysokich pozycjach w hierarchii wartości potrzebują wzorca w osobie nauczyciela, którego system aksjologiczny opiera się na wartościach uniwersalnych takich jak: prawo do życia i wolności, podmiotowość i tożsamość człowieka, tolerancja, godziwy poziom bytu materialnego i duchowego i który sam sytuuje zdrowie wysoko w systemie wartości. Od właściwie uformowanego systemu wartościowania zależą określone zachowania człowieka, również te dotyczące jego zachowań zdrowotnych ${ }^{12}$.

W wychowaniu zdrowotnym obok nauczyciela dominująca rola przypada rodzicom, dlatego powinnością nauczyciela jest dokonanie diagnozy środowiska rodzinnego dzieci i następniewspółpracaw zakresie wychowania zdrowotnego. Pełnienie roli kreatora zdrowia w przedszkolu, polega nie tylko na realizacji tego zagadnienia podczas zajęć dydaktycznych z dziećmi ale właśnie na zgodnej współpracy z rodzicami. Promowanie zdrowia w przedszkolu, by było prawidłowe i skuteczne, musi przebiegać na kilku płaszczyznach: na wymianie informacji między nauczycielem a rodzicami o przebiegu rozwoju dziecka, aktualnym stanie zdrowia, na zapoznaniu rodziców z działalnością wychowawczo-dydaktyczną przedszkola na rzecz zdrowia dzieci, zachęcaniu rodziców do utrwalania postaw, umiejętności i nawyków higieniczno-zdrowotnych nabytych przez dziecko w przedszkolu, włączaniu rodziców w rozwiązywanie problemów związanych z ochroną, szanowaniem i pomnażaniem zdrowia dzieci oraz stosowania szczególnych

12 B. Kuras, Szkolna edukacja zdrowotna, „Edukacja i Dialog” 2005, nr 4, s. 2-5. 
środków zaradczych w przypadku rodziców działających na szkodę zdrowia dzieci ${ }^{13}$.

Nauczyciel podczas zajęć otwartych dla rodziców może realizować te zagadnienia, by je potem omówić z rodzicami na zebraniu lub podczas rozmów indywidualnych. Można także w tym celu wykorzystać gazetki i kąciki przedszkolne przeznaczone dla rodziców, by tam umieszczać ciekawe, ważne informacje czy porady. Można to także czynić przez media, czyli np. stronę internetową placówki lub poprzez przedszkolne pisemka oraz samodzielnie opracowane przez nauczyciela ulotki. Warto np. zorganizować w przedszkolu Festiwal Zdrowego Stylu Życia, Tydzień Zdrowia i inne. Można organizować w przedszkolu cykl pogadanek, podczas których prelekcje będą głosić specjaliści: pediatrzy, ortopedzi, stomatolodzy, diabetolodzy i inni. Można także edukować rodziców w zakresie organizacji czasu wolnego dzieci. Przedszkole w zakresie edukacji rodziców, dotyczącej m.in. ochrony przed różnymi niebezpieczeństwami, zachowaniu ostrożności wobec nieznanych przedmiotów, zwierząt i zjawisk oraz bycia wraz z dziećmi świadomymi uczestnikami ruchu drogowego, może zapraszać do przedszkola policjantów, strażaków, strażników miejskich oraz ratowników medycznych. Często nauczycieli niepokoi fakt, że pomimo krzewienia przez nich idei promocji zdrowia wielu wychowanków nie stosuje wdrażanych przez wychowawców zasad i nie zna podstawowych wiadomości z zakresu edukacji zdrowotnej. Przyczyn tego stanu rzeczy należałoby może szukać w sytuacji rodzinnej tych dzieci. Powszechnie bowiem wiadomo, że rodzice są najważniejszymi edukatorami swoich dzieci, a przede wszystkim stanowią dla nich wzór do naśladowania. Jeżeli rodzice nie będą lokować zdrowia wysoko w hierarchii wartości, to dzieci także nie będą prezentowały postawy dbającej o zdrowie. Dlatego warto w tym zakresie wspierać się spotkaniami z dietetykami $\mathrm{i}$ innymi specjalistami. Dobrym pomysłem na innowacje w tym zakresie byłyby zajęcia dydaktyczne na temat „Gotuję z rodzicami i zdrowo jem”, podczas których rodzice wspólnie z dziećmi przygotowaliby niewielki ulubiony rodzinny posiłek, a potem byłaby wspólna degustacja z komentarzem dla rodziców, jakie błędy popełniają przy komponowaniu posiłków dla dzieci i rodziny oraz czy znają piramidę żywienia.

13 K. Żuchelkowska, Edukacja zdrowotna w przedszkolu, Wydawnictwo Uniwersytetu Kazimierza Wielkiego, Bydgoszcz 2013, s. 52-53. 
Innym razem mogą to być zajęcia pod nazwą „Kulinarne zmagania przedszkolaków” lub „Tworzymy zdrową książkę kucharską”.

Nieodzownym pomocnikiem w organizacji wszystkich zajęć, także tych z zakresu edukacji zdrowotnej jest bogata literatura dla dzieci. Utwory napisane prozą, krótkie opowiadania czy powiastki, a przede wszystkim utwory wierszowane, krótkie fraszki, lub zagadki o zdrowiu, higienie, ruchu drogowym pomagają zapamiętać dzieciom wiele zasad, przepisów i reguł. Zadaniem rodzica jest wyuczenie się wspólnie z dzieckiem w domu takiego wierszyka, który potem ono zaprezentuje np. podczas przedszkolnego przedstawienia, konkursu czy innej zabawy. To tylko nieliczne przykłady takiej działalności. Sądzimy, że działania prozdrowotne staną się sensowne i skuteczne właśnie m.in. dlatego, że będą w nich uczestniczyć rodzice dzieci przedszkolnych.

\section{Możliwości współpracy przedszkola z rodzicami w obszarze organizacji wycieczek i innych form turystki i krajoznawstwa}

Rozwój człowieka przebiega specyficznie dla każdej jednostki, jest wynikiem indywidualnych cech dziedzicznych i wrodzonych oraz wpływów środowiskowych. Bezpośrednim warunkiem rozwoju jest aktywny udział jednostki w nabywaniu indywidualnego doświadczenia w toku edukacji opartej na działaniu, przeżywaniu, odkrywaniu. Podstawą aktywności małego dziecka jest zabawa. Jest to forma spontaniczna i dowolna, której towarzyszy zadowolenie i przyjemność. W zabawach dziecko zaspokaja wszystkie swoje potrzeby oraz kształtuje twórczy charakter. Poprzez dowolny dobór tematyki i sposobu aktywności w zabawie, dziecko urzeczywistnia swoje marzenia, dążenia, zainteresowania, czyni to, czego pragnie. W środowisku przedszkolnym oprócz zabawy, dzieci uczestniczą w wielu innych formach aktywności. Są to zajęcia o charakterze intelektualnym, artystycznym, społecznym, ruchowym, użytkowym, samoobsługowym. Nauczyciel podczas zaplanowanej działalności edukacyjnej wspomaga dziecko w zdobywaniu doświadczeń, wiedzy, nawyków, umiejętności, inspiruje je do podejmowania aktywności, nawiązywania interakcji ze środowiskiem. Jedną z form zajęć w przedszkolu, za pomocą której dzieci mają okazję wszechstronnie rozwijać wymienione sfery osobowości są spacery i wycieczki organizowane okazjonalnie. Odgrywają one ogromną 
rolę w procesie edukacji małego dziecka, m.in. przygotowując do przyszłej roli turysty oraz stanowią pierwszy kontakt z formami turystyki i krajoznawstwa. Wycieczka jest najwłaściwszą formą i najciekawszą przybliżania przedszkolakom przyrody, odkrywania jej tajemnic i nawiązywania z nią emocjonalnego kontaktu.

Udział dzieci w wycieczkach, będących główną formą uprawiania turystyki, wpływa na:

- poznanie najbliższego otoczenia i miejsca zamieszkania dziecka,

- harmonijny rozwój psychofizyczny,

- utrwalenie nawyku przebywania na świeżym powietrzu bez względu na porę roku, nawet w dni niepogodne, zahartowanie na zmiany pogody i trudy pobytu w terenie,

- utrwalenie zainteresowań różnymi formami aktywności ruchowej możliwymi do uprawiania w terenie,

- zaspokojenie głodu przygód i wrażeń, wzbogacenie osobowości dziecka ${ }^{14}$.

Dzieci w wieku przedszkolnym uczestniczą w takich formach turystyki, jak: turystyka campingowa, wczasy, turystyka zagraniczna, wyjazdy świąteczne. Ale to właśnie wycieczka jest najpopularniejsza, spełnia rolę wypoczynkową i poznawczą oraz kształtuje postawy społeczne przedszkolaka. Na ogół w przedszkolu organizuje się kilka wycieczek w roku krótszych i dłuższych. Charakter turystyczno-krajoznawczy mają te dłuższe, całodzienne. Ze względu na wiek dzieci wymagają one bardzo starannego i przemyślanego przygotowania, zorganizowania posiłków, miejsc do odpoczynku, dodatkowej opieki ze strony dorosłych, bezpiecznego transportu. Maria Studzińska podkreśla, że spacery i wycieczki to pożądana, choć trudna dla nauczyciela forma pracy z dziećmi. Trzeba się do niej szczególnie przygotować, uwzględniając:

- możliwości fizyczne dzieci związane z dojściem lub dojechaniem do wybranego miejsca;

- znajomość danego terenu;

- cel i tematykę spaceru lub wycieczki;

- znajomość obiektów, które dzieci będą obserwować15.

14 T. Łobożewicz, Krajoznawstwo i turystyka w szkole, WSiP, Warszawa 1985, s. 30-31.

15 M. Studzińska, Dzieci przedszkolne poznaja przyrodę ożywioną, WSiP, Warszawa 1989, s. 103. 
Wycieczki organizowane dla przedszkolaków, szczególnie tych starszych są źródłem wielkich emocji i radości. Potrzeba wyrażania przeżyć i doznań dziecięcych w czasie wycieczek przekłada się na język sztuki, symboli, gestów, mimiki. Dobrze zorganizowana wycieczka jest okazją do zdobycia wiedzy o otaczającej przyrodzie i zmianach, jakie w ciągu roku w niej zachodzą. Szczególnie wartościowe jest to, że dzieci doświadczają bezpośredniego kontaktu z rzeczywistością i mogą obserwować obiekty przyrodnicze oraz zachodzące procesy i zjawiska w ich wielostronnym uwarunkowaniu. Udział w wycieczkach kształtuje umiejętność dokonywania obserwacji przyrodniczych w terenie, sprzyja pogłębianiu i rozwijaniu zainteresowań, budzi wrażliwość na piękno przyrody i chęć dbania o nią, uczy zdobywania wiedzy przez bezpośredni kontakt z naturą.

Wartość wycieczki w zakresie zdobywania wiedzy i kształtowania postaw w dużym stopniu warunkuje dostosowanie miejsca jej odbywania. Dlatego nauczyciele muszą wziąć pod uwagę różne okoliczności decydując o ostatecznym wyborze. Z całą pewnością wytyczną będą zainteresowania dzieci i wymagania programowe. Niemały wpływ na selekcję miejsc odbywania wycieczek mają możliwości organizacyjne i finansowe przedszkola oraz rodziców. Zainteresowanie dzieci wycieczkami jest ogromne. Nauczyciele chętnie organizują wycieczki dla dzieci. Uważają, że pomimo długich przygotowań i ogromnej odpowiedzialności branej za dzieci, jest to forma niezbędna w procesie dydaktyczno-wychowawczym. Obok walorów poznawczych wycieczki mają duże znaczenie w kształtowaniu postaw wobec przyrody, postaw patriotycznych, wartościowych cech charakteru oraz umiejętności współżycia w zespole oraz są źródłem bogatych przeżyć estetycznych. Dzieci, zamiast słuchać opisów przyrody i oglądać ilustracje, mogą odkrywać ją samodzielnie poprzez działania i odczucia zmysłowe. Doznania polisensoryczne w bezpośrednim obcowaniu z przyrodą poprzez wzrok, słuch, dotyk, smak są podstawą tworzenia pojęć o otoczeniu. Podczas działania i odczuwania zmysłowego dziecko gromadzi doświadczenia, które wykorzystuje do korygowania i modyfikowania pojęć, będących podstawą rozumienia świata. Obraz otoczenia, który dzieci budują staje się coraz bogatszy, bardziej zróżnicowany i bardziej zgodny z rzeczywistością. Aby te zdobyte doświadczenia i przeżycia były trwałe muszą być od powiednio przetworzone. Poprzez takie formy przetwarzania jak opowiadanie, wiersz, rysunek, śpiew, teatr, a przede 
wszystkim zabawa repertuar doświadczeń gromadzonych przez dziecko daje mu wiedzę i zrozumienie oraz podstawy naukowego poglądu na świat. Podstawowym zadaniem wycieczek jest zapewnienie ich uczestnikom aktywnego wypoczynku, hartowanie stanu zdrowia oraz wzmocnienie sprawności fizycznej i psychicznej. Wycieczki kształtują u dzieci nawyk racjonalnego spędzania czasu w sposób czynny, co jest niezbędnym elementem prozdrowotnego stylu życia. Szczególnie wycieczki, których program przewiduje piesze wędrówki, sprzyja wyrabianiu odporności przeciw chorobom, hartowaniu i wytrzymałości. Podczas wysiłku wzmaga się czynność serca, płuc, wzrasta przemiana materii, co skutkuje zwiększeniem apetytu. Dlatego dzieci są radosne, mają zaspokojoną potrzebę ruchu i chętnie zjadają przywieziony z przedszkola posiłek.

Wiedzę i umiejętności dbania o zdrowie dziecko zdobywa w domu rodzinnym poprzez gromadzenie doświadczeń i edukację dostosowaną do jego indywidualnych potrzeb. Wraz z innymi członkami rodziny dziecko powinno uczestniczyć w różnych formach aktywności ruchowej. Aktywizacja fizyczna dzieci może być realizowana poprzez: taniec, pracę, rekreację, turystykę, zabawę. Najbardziej zalecane formy wychowania zdrowotnego w rodzinie sprzyjające organizacji korzystnych zdrowotnie doświadczeń jej członków to:

- wycieczki poza dom,

- terenowe wyjazdy weekendowe,

- terenowe programy urlopowe,

- treningi zdrowotne,

- terenowe sporty przestrzenne,

- terenowe formy rehabilitacyjno-terapeutyczne.

Wśród nich na czoło wysuwają się formy związane z dłuższą lub krótszą wycieczką, czyli formy turystyczno-krajoznawcze.

Nauczyciele i ich wychowankowie przypisują wycieczce duże znaczenie. Wycieczka zatem powinna być częściej wykorzystywaną formą edukacji małego dziecka zarówno w przedszkolu jak i w rodzinie. Nauczyciele i rodzice powinni szukać źródeł inspiracji i programów poznawania otoczenia poprzez działalność turystyczno-krajoznawczą. Wśród takich inicjatyw, mogą być wspólne wypady nauczycieli przedszkola i dzieci z rodzicami do miejsc agroturystycznych znajdujących się w pobliżu przedszkola, włączenie dzieci przedszkolnych i rodzin wraz z kadrą placówek w rozwój prorodzinnej oferty turystycznej 
miejscowości i regionu. Warto być może pomyśleć o propagowaniu turystyki i krajoznawstwa integrując społeczność przedszkolną i organizować wspólne rajdy, złazy z udziałem rodziców i wszystkich pracowników przedszkola. Taką ciekawą formą, którą można by zorganizować byłoby np. odwiedzanie wiosek tematycznych. Są takie np. w województwie kujawsko-pomorskim. Można wybrać się wspólnie do Wioski Miodowej, Kwiatowej czy Górniczej. Inną inicjatywą mogło by być opracowanie programu przedszkola, którego założeniem byłoby zachęcanie dzieci i ich rodziców do aktywnego, zdrowego oraz twórczego spędzania czasu wolnego. Zajęcia mogą dotyczyć poznania bliższego i dalszego regionu, jego środowiska przyrodniczego, tradycji, zabytków kultury, historii oraz baśni i legend. Mogą to być zajęcia np. takie jak: niedziele w muzeum, spacer po parkach czy lesie. Warto wybrać się na spotkanie $\mathrm{z}$ ciekawymi ludźmi z miasta czy regionu (np. twórcami ludowymi lub przedstawicielami ciekawych, ginących zawodów, uczestniczyć w imprezach folklorystycznych i obrzędowych i innych). Dobrą zachętą do tego typu działań są organizowane przez przedszkola rodzinne pikniki, turnieje sportowe, festyny czy biesiady połączone z degustacją potraw regionalnych, ekologicznych, zdrowych np. przetworów mlecznych, w których uczestnikami konkursów są dzieci wspólnie z rodzicami. Możliwości jest sporo, a kreatywność nauczyciela i rodziców jako podmiotów edukacji i partnerskiej współpracy nieograniczona.

\section{Kilka refleksji}

Nauczyciele przedszkola powinni nadać szczególną rolę współpracy z rodzicami. To właśnie rodzice wielokrotnie oceniają jakość pracy przedszkola. $Z$ racji swego powołania i kompetencji nauczyciele mają obowiązek inicjowania i rozwijania tych kontaktów. Tak więc praca pedagogiczna nauczyciela w zakresie edukacji zdrowotnej w przedszkolu oraz organizacji wycieczek czy innych form turystyki i krajoznawstwa powinna koncentrować się na podejmowaniu działań promujących zdrowy i higieniczny tryb życia oraz stwarzać okazje do tego, by dzieci mogły zdobywać wiadomości i umiejętności oraz wykorzystywać je w praktyce. Rodziców należy zawsze traktować jako sojuszników przedszkola, którym zależy na pewno na dobru ich dzieci, ale którzy czasami potrzebują pomocy i wsparcia m.in. w zakresie 
upowszechniania wiedzy i kształtowania zachowań prozdrowotnych czy organizacji czasu wolnego swoich pociech. Dlatego pracownicy przedszkola powinni proponować rodzicom wiele form kontaktu, sugerować im obszary i sposoby działania na rzecz rozwoju dziecka. Ponadto powinni zadbać, by w edukacji dzieci przedszkolnych tak dobierać treści, aby pomagać dzieciom w usamodzielnieniu się, przez poznanie własnych możliwości i „podawać rękę” w tym zakresie ich rodzicom $\mathrm{w}$ trudnej sztuce porządkowania świata. Warto zachęcać rodziców do zgłaszania swoich propozycji w zakresie organizowania tego typu edukacji. Tylko zgodne współdziałanie obu tych środowisk jest najlepszym rodzajem integracji, która może zapewnić warunki prawidłowego wychowania i pobudzania rozwoju dziecka ${ }^{16}$.

\begin{abstract}
A kindergarten gives extensive opportunities for cooperation with parents. The article is limited to present two aspects of cooperation. One area concerns health education, which can and should combine and integrate the activities of kindergarten teachers and parents, concerning children's knowledge acquisition and formation of health-oriented behaviour. The second area concerns preparing preschool children for the future role of a tourist. Advantages of tourism for a child's development were presented, including trips as an organizational form of kindergarten work. In addition to evidence confirming the numerous cognitive, health, cultural, and aesthetic values of trips, the importance of cooperation between a kindergarten and parents in this regard was highlighted. The article also contains many proposals for methodological solutions for the discussed issues.
\end{abstract}

\title{
Bibliografia
}

Bulera M., Sobieszczyk M., Wybrane aspekty pracy nauczyciela sprzyjajace tworzeniu w przedszkolu edukacji wysokiej jakości-doniesienie z badań, [w:] R. Cierzniewska (red.), Ewaluacja jakości pracy nauczyciela, Wydawnictwo Akademii Bydgoskiej, Bydgoszcz 2003.

Demel M., Pedagogika zdrowia, WSiP, Warszawa 1980.

16 M. Bulera, M. Sobieszczyk, Wybrane aspekty pracy nauczyciela sprzyjajace tworzeniu w przedszkolu edukacji wysokiej jakości - doniesienie z badań, [w:] R. Cierzniewska (red.), Ewaluacja jakości pracy nauczyciela, Wydawnictwo Akademii Bydgoskiej, Bydgoszcz 2003, s. 344. 
Gaweł A., Pedagodzy wobec wartości zdrowia, Wydawnictwo Uniwersytetu Jagiellońskiego, Kraków 2003.

Karski J.B., Praktyka i teoria promocji zdrowia, wybrane zagadnienia, Wydawnictwo CeDeWu, Warszawa 2003.

Klim-Klimaszewska A., Pedagogika przedszkolna, Polski Instytut Wydawniczy, Warszawa 2005.

Kuras B., Szkolna edukacja zdrowotna, „Edukacja i Dialog” 2005, nr 4.

Łobożewicz T., Krajoznawstwo i turystyka w szkole, WSiP, Warszawa 1985.

Siciński A., Styl życia - problemy pojęciowe i teoretyczne, [w:] A. Siciński (red.), Styl życia. Koncepcje i propozycje, PWN, Warszawa 1976.

Studzińska M., Dzieci przedszkolne poznaja przyrodę ożywioną, WSiP, Warszawa 1989.

Śliwa M.M., Wychowanie zdrowotne. Zarys teorii i metodyki, Polskie Towarzystwo Oświaty Zdrowotnej, Katowice 2001.

Tąpała E., Rodzice w szkole, „Życie Szkoły” 2003, nr 5.

Woynarowska B., Zdrowie i szkoła, Wydawnictwo Lekarskie PZWL, Warszawa 2000.

Żuchelkowska K., Edukacja zdrowotna w przedszkolu, Wydawnictwo Uniwersytetu Kazimierza Wielkiego, Bydgoszcz 2013.

Żuchelkowska K., Wojciechowska K., Promocja zdrowia w edukacji dzieci przedszkolnych, MARGRAFSEN, Bydgoszcz 2000. 